Indonesian Journal of Electronics and Instrumentation Systems (IJEIS)

Vol.9, No.2, October 2019, pp. 141 150

ISSN (print): 2088-3714, ISSN (online): 2460-7681

DOI: https://doi.org/10.22146/ijeis.49173

\title{
Analisis Respons Sensor Electroni Tongue terhadap Sampel Ganja menggunakan Support Vector Machine
}

\author{
Wikan Haryo Rahmantyo*1, Danang Lelono ${ }^{2}$ \\ ${ }^{1}$ Program Studi Elektronika dan Instrumentasi, DIKE, FMIPA, UGM, Yogyakarta, indonesia \\ ${ }^{2}$ Departemen Ilmu Komputer dan Elektronika, FMIPA UGM, Yogyakarta, Indonesia \\ e-mail: *11 wikan.haryo.r@mail.ugm.ac.id, ${ }^{2}$ danang@ugm.ac.id
}

\begin{abstract}
Abstrak
Sensor lidah elektronik (electronic tongue) yang terdiri dari 16 larik sensor berbahan lipid TOMA dan OA selama ini digunakan untuk mengklasifikasi sampel ganja murni, ganja bercampur teh dan ganja bercampur tembakau yang telah dilakukan belum melibatkan tahap seleksi fitur sehingga banyak data terduplikasi. Seleksi fitur dilakukan sebagai metode optimasi larik sensor menggunakan PCA. Analisis data menghasilkan nilai loading, kemudian diinterpretasikan menjadi plot yang menunjukkan kontribusi masing-masing sensor terhadap pembentukan variable baru pada PCA, dan diketahui kemiripan performa sensor. Kemiripan peforma sensor tersebut dianalisis menggunakan uji korelasi sehingga diketahui adanya sensor-sensor yang menghasilkan informasi yang redundan. Validasi dilakukan menggunakan metode klasifikasi SVM dan dilakukan perbandingan performa klasifikasi terhadap larik sensor asli.

Optimasi sensor menghasilkan subset fitur dengan 6 buah sensor pada sampel ganja-teh dan subset fitur dengan 3 buah sensor pada sampel ganja-tembakau. Keenam sensor yang berperan dalam mencirikan sampel ganja-teh ialah Sensor 7, Sensor 10, Sensor 12, Sensor 13, Sensor 14 dan Sensor 15. Ketiga sensor yang berperan dalam mencirikan sampel ganjatembakau ialah Sensor 3, Sensor 7 dan Sensor 14. Optimasi sensor yang telah dilakukan menghasilkan akurasi klasifikasi sebesar 100\% dan mempersingkat running time dengan selisih 0,578 mikrodetik pada pengujian sampel ganja-teh dan selisih 1,696 mikrodetik pada pengujian sampel ganja-tembakau.
\end{abstract}

Kata kunci-electronic tongue, support vector machine, PCA, optimasi sensor, seleksi fitur

\begin{abstract}
Electronic tongue sensors consisting of 16 sensor array made of TOMA and OA lipids that have been used to classify samples of pure cannabis, cannabis mixed with tea and cannabis mixed with tobacco does not involve the feature selection technique so that a lot of duplicated data is generated from data sampling. Feature selection is performed using PCA. Data analysis resulted in loading values shows the contribution of each sensor, and the similarity in sensor performance in characterizing samples, then analyzed using the correlation test so that the sensors that produce redundant information are known. Validation is performed using the SVM method and the classification performance is compared to the original sensor.

The sensor optimization produces a subset of features with 6 sensors (Sensor 7, Sensor 10, Sensor 12, Sensors 13, Sensor 14 and Sensor 15) in the cannabis-tea sample test and a feature subset with 3 sensors (Sensor 3, Sensor 7 and Sensor 14) in the cannabis-tobacco sample test. Sensor optimization that has been done produced classification accuracy by $100 \%$ and shorten the running time by a difference of 0.578 microseconds in the test of cannabis-tea samples and a difference of 1.696 microseconds in the test of cannabis-tobacco samples.
\end{abstract}

Keywords - electronic tongue, support vector machine, PCA, sensor optimization, feature selection

Received July 13 $3^{\text {th }}, 2019 ;$ Revised October 18 ${ }^{\text {th }}, 2019 ;$ Accepted October $23^{\text {th }}, 2019$ 


\section{PENDAHULUAN}

Ganja (cannabis sativa) adalah zat terlarang yang paling banyak digunakan di Indonesia dengan sekitar dua juta pengguna pada tahun 2014 [1]. Pengamatan yang dilakukan secara fisik, jika tanaman ini telah dikeringkan sulit dibedakan dengan teh dan tembakau kering. Sehingga untuk membedakan atau mendeteksi tumbuhan tersebut diperlukan metode maupun peralatan khusus, karena jika dilakukan dengan kontak langsung melalui indera perasa maupun indera penciuman manusia dapat berakibat fatal bagi individu tersebut [2][3].

Badan Narkotika Nasional (BNN) mengembangkan peralatan-peralatan maupun metodemetode untuk mendeteksi narkotika, antara lain menggunakan anjing pelacak dan melibatkan tim medis. Namun metode ini selain mahal, diperlukan diagnosis terlebih dahulu sehingga respon yang dihasilkan cukup lama. Cara lainnya adalah dengan menggunak an metode GC-MS atau LC-MS namun membutuhkan biaya yang sangat mahal, operator khusus dan persiapan sampel yang rumit [4]. Oleh karena itu diperlukan metode pendeteksi ganja pada teh dan tembakau berdasarkan pola rasa pada sampel. Pola rasa pada sampel dapat dideteksi oleh lidah manusia dan juga dapat dideteksi melalui teknologi instrumentasi yang menirukan kerja lidah manusia. Bentuk instrumen yang dimaksud adalah lidah elektronik (electronic tongue) yang bekerja meniru indera manusia berupa lidah sebagai perasa [5].

Pada sistem sensor multi-kanal tidak terdapat ketentuan jumlah larik sensor. Saputro memvariasikan kandungan lipid penyusun sensor sehingga dapat diketahui nilai respons, selektivitas dan sensitivitas dari enam belas variasi persentase kandungan lipid TOMA maupun OA di setiap sensor [6]. Setelah diketahui respons sensor dari berbagai variasi kandungan lipid tersebut, kemudian pada penelitian ini dilakukan optimasi larik sensor dan klasifikasi pada dataset yang didapat dari pencuplikan. Pada penelitian ini, optimasi sensor dilakukan dengan tahap penyeleksian fitur (sensor). Tujuan yang ingin dicapai dari proses seleksi fitur adalah untuk menemukan subset fitur minimal dari suatu domain permasalahan dengan tingkat akurasi klasifikasi yang sesuai dalam merepresentasikan data awal. Setelah seleksi fitur diterapkan pada analisis sensor electronic tongue, didapat larik sensor baru dengan jumlah sensor minimal, namun tetap memiliki peforma yang baik dalam mencirikan sampel ganja beserta campuran teh atau tembakau. Penyeleksian fitur yang dilakukan pada penelitian ini didasarkan dari analisis komponen utama (principal component analysis, PCA).

Kinerja subset larik sensor baru dalam mengenali pola rasa sampel diuji dan dianalisis pada tahap klasifikasi. Metode klasifikasi yang diterapkan pada penelitian ini adalah sebuah pembelajaran mesin support vector machine (SVM). Klasifikasi menggunakan SVM dipilih karena sesuai dengan karakteristik data yang dianalisis, yang dapat melakukan klasifikasi nonlinier dan multikelas[7]. Selain itu SVM memiliki peforma klasifikasi yang baik di berbagai bidang aplikasi seperti bioinformatika, pengenalan tulisan tangan, klasifikasi teks dan lain sebagainya. Subset larik sensor optimal dipilih berdasarkan peforma klasifikasinya yang meliputi akurasi klasifikasi dan running time. Tujuan yang ingin dicapai pada penelitian ini adalah melakukan seleksi fitur menggunakan PCA serta melakukan validasi menggunakan SVM untuk optimasi sensor electronic tongue berbasis lipid TOMA dan OA pada ganja murni serta ganja yang bercampur tembakau dan ganja yang bercampur teh.

\section{METODE PENELITIAN}

\subsection{Rancangan Sitem Secara Umum}

Studi literatur dilakukan untuk mencari informasi permasalahan-permasalahan dan mengkaji tentang metode-metode yang pernah dilakukan pada penelitian sebelumnya, sehingga diperoleh permasalahan penelitian. Selain itu, dengan adanya studi literatur, penelitian dapat dilakukan dengan tahapan-tahapan yang jelas sehingga tujuan penelitian dapat tercapai.

IJEIS Vol. 9, No. 2, October 2019: 141 - 150 
Tahapan selanjutnya mempersiapkan data agar siap digunakan pada tahap seleksi fitur dan klasifikasi. Data respons setiap perulangan diambil nilai rata-ratanya karena telah mewakili keseluruhan data sehingga ekstrak ciri yang didapat menjadi nilai yang mewakili karakter atau ciri dari sampel. Nilai tersebut dinormalisasi, kemudian digunakan sebagai bahan analisis fitur.

Proses seleksi fitur akan menghasilkan subset fitur sensor baru yang lebih sederhana. Penggunaan larik sensor yang lebih sederhana mengurangi waktu komputasi dan biaya dalam perancangan lidah elektronik di waktu mendatang. Selain itu, seleksi fitur dapat mencegah terjadinya overfiting. Overfitting terjadi karena fitur yang berkontribusi rendah dalam klasifikasi ikut dilatih dalam tahap pembelajaran mesin.

Kinerja larik sensor dalam mengenali pola rasa sampel diuji dan dianalisis oleh sebuah pembelajaran mesin menggunakan metode support vector machine. Subset larik sensor optimal dipilih berdasarkan peforma klasifikasinya yang meliputi akurasi klasifikasi dan running time. Kesimpulan diperoleh dari hasil penelitian yang menjawab tujuan dari penelitian yang dilakukan.

\subsection{Bahan dan Peralatan}

Tabel 1 Alat-alat yang digunakan pada penelitian

\begin{tabular}{|c|c|c|}
\hline \multirow{7}{*}{ Package } & Perangkat/tools & Keterangan \\
\hline & Hmisc & Menghitung koefisien dan $p$-value korelasi \\
\hline & CaTools & $\begin{array}{l}\text { Membagi data respons sensor menjadi dua bagian, yaitu } \\
\text { training set dan test set }\end{array}$ \\
\hline & e1071 & $\begin{array}{l}\text { Melatih dan menguji data menggunakan machine learning } \\
\text { SVM }\end{array}$ \\
\hline & FactoMineR & Menjalankan analisis PCA \\
\hline & factoextra & Menampilkan visualisasi hasil analisis PCA \\
\hline & ggbiplot2 & Visualisasi data \\
\hline \multirow{3}{*}{ Komputer } & \multirow{3}{*}{ Lenovo G400 } & RAM: 4GB \\
\hline & & Processor: Intel Pentium 2020M 2,4GHz \\
\hline & & Sistem Operasi: Windows 10 \\
\hline
\end{tabular}

Alat yang digunakan untuk menganalisis data respons sensor pada penelitian ini adalah sebuah sebuah bahasa pemrograman R. Bahasa R dipilih karena memiliki kemampuan yang baik pada bidang analisis data[8]. Pada penelitian ini, bahasa $\mathrm{R}$ dijalankan menggunakan antarmuka atau IDE (Integrated Development Environment) RStudio. Pada bahasa pemrograman $\mathrm{R}$, dibutuhkan berbagai library untuk menganalisis data. Library yang digunakan berisi set perintah yang terdapat pada package. Package adalah kumpulan fungsi bahasa $\mathrm{R}$ yang mengandung kode dan contoh sampel data yang dikembangkan oleh komunitas. Pada awal program dipasang, telah terpasang beberapa package bawaan. Package lain perlu ditambahkan sesuai dengan kebutuhan analisis pengguna. Seluruh package tersimpan di server CRAN (The Comprehensive $\mathrm{R}$ Archive Network) yang dapat diakses secara online untuk melakukan pemasangan package. Detail package yang digunakan dalam penelitian ini beserta perangkat lain yang mendukung penelitian dijelaskan pada Tabel 1.

\subsection{Ekstraksi Fitur}

Blok diagram ekstraksi fitur ditunjukkan pada Gambar 1. Ekstraksi fitur/ciri adalah proses pengambilan sebagian data/parameter dari suatu pola rasa.

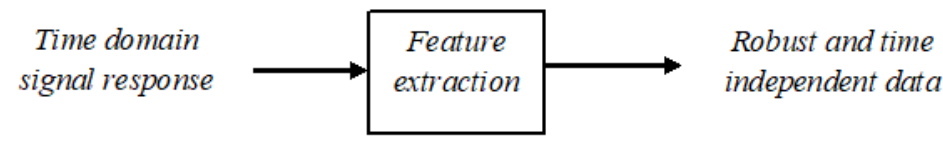

Gambar 1 Blok diagram ekstraksi fitur

Tujuan dilakukan ekstraksi ciri adalah untuk mengekstrak informasi yang kuat (robust) dari ciri respon sensor sehingga informasi yang berlebihan dapat dikurangi, dan informasi 
tersebut dapat mewakili pola sampel yang berbeda dengan baik [9]. Pada penelitian ini, ekstaksi ciri dilakukan dengan mengambil nilai rerata dari setiap pengujian sesuai dengan persamaan (1),

$$
\bar{x}_{j}=\frac{\sum_{i}^{n} x_{i j}}{n}
$$

dengan $\bar{x}_{j}$ adalah rerata pengamatan $\mathrm{j}$ yang dihasilkan dari $\mathrm{n}$ kali pengamatan. Nilai tersebut kemudian digunakan sebagai objek penerapan metode seleksi fitur dan klasifikasi.

\subsection{Normalisasi Fitur}

Normalisasi fitur atau feature scaling adalah metode yang digunakan untuk membuat standarisasi rentang data dari tiap fitur, sehingga data numerik pada set data memiliki rentang (scale) yang sama. Tujuan dilakukannya tahap normalisasi fitu adalah agar tidak ada suatu variabel data yang mendominasi variabel data lainnya. Rumus yang digunakan untuk menjalankan proses normalisasi fitur ditunjukkan pada persamaan (3). Setelah diterapkan tahap normalisasi fitur, rentang nilai masing-masing fitur/variabel menjadi $[1,0]$.

$$
x_{\text {norm }}=\frac{x-\min (x)}{\max (x)-\min (x)}
$$

Perbedaan rentang nilai akan menyebabkan adanya perbedaan hasil analisis PCA dan menimbulkan masalah dalam model machine learning[10].

\subsection{Seleksi Fitur}

Tahap seleksi fitur penelitian ini diperlihatkan pada diagram alir Gambar 2. Tahap seleksi fitur dilakukan dengan menerapkan metode analisis komponen utama (PCA) dan mempertimbangkan korelasi antar fitur. Fitur atau variabel yang dimaksud dalam tahap ini adalah sensor yang digunakan pada pengambilan data terhadap sampel. Algoritma analisis PCA menghasilkan persentase kontribusi dari masing-masing fitur/sensor. Persentase kontribusi masing-masing fitur yang diperoleh dari nilai loading memberikan indikasi variabel (sensor) asli mana yang penting atau berpengaruh terhadap pembentukan variabel baru. Semakin tinggi nilai loading, maka variabel lama tersebut semakin berpengaruh terhadap pembentukan variabe baru.

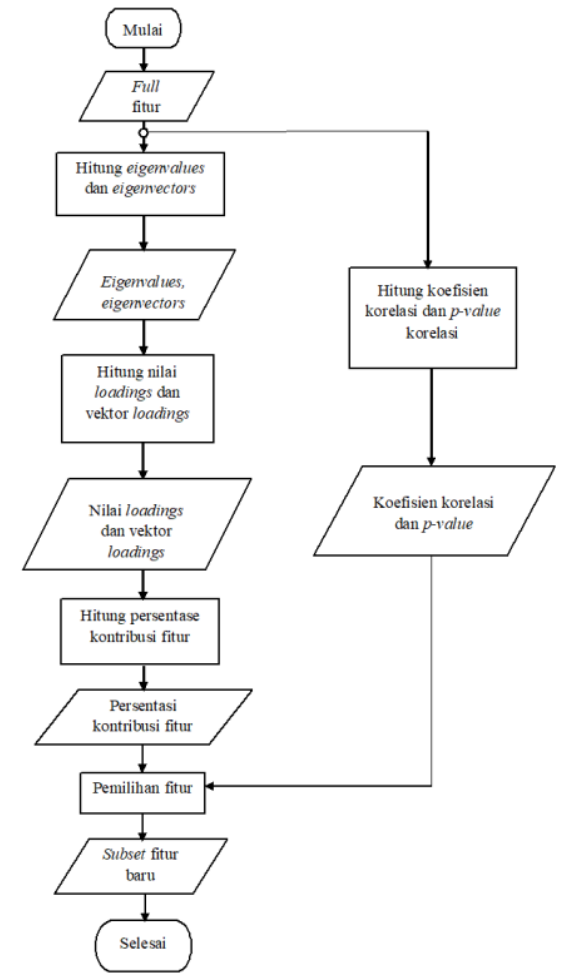

Gambar 2 Diagram alir seleksi fitur

IJEIS Vol. 9, No. 2, October 2019: 141 - 150 
Tahap berikutnya adalah dilakukan analisis korelasi dari setiap pasangan fitur/sensor, sehingga dihasilkan koefisien korelasi dan $p$-value korelasi. Tahap ini perlu dilakukan karena analisis PCA hanya memberikan informasi kontribusi variabel-variabel lama terhadap pembentukan variabel baru, sedangkan persamaan karakter antar variabel perlu diketahui.

Hal ini disebabkan karena elektroda sensor electronic tongue tersusun dari zat-zat yang divariasikan komposisinya, sehingga memungkinkan adanya persamaan karakter sensor dalam merespons sampel. Metode uji korelasi yang dipilih yaitu metode Pearson, karena mengukur hubungan sepasang variabel yang mengalami perubahan nilai secara linier terhadap perubahan objek yang diamati. Pasangan sensor yang mempunyai kemiripan karakter akan dipilih salah satu berdasarkan kontribusi yang lebih besar terhadap pembentukan variabel baru.

\subsection{Klasifikasi SVM}

\subsubsection{Pembagian Data}

Pembagian data pada pembelajaran mesin SVM diperlihatkan pada diagram blok pada Gambar 3. Dataset respons sensor dibagi menjadi dua bagian, yaitu data latih dan data uji. Tidak ada perbandingan baku yang menjadi dasar perbandingan jumlah data uji dengan data latih, namun pada penelitian ini ditetapkan perbandingan 1:1 agar porsi data yang dilatih sama dengan data yang digunakan untuk pengujian. Data latih harus berbeda dengan data uji dan harus dipilih secara acak untuk memperoleh peforma klasifikasi yang baik dan diperoleh estimasi yang reliable dari error rate.

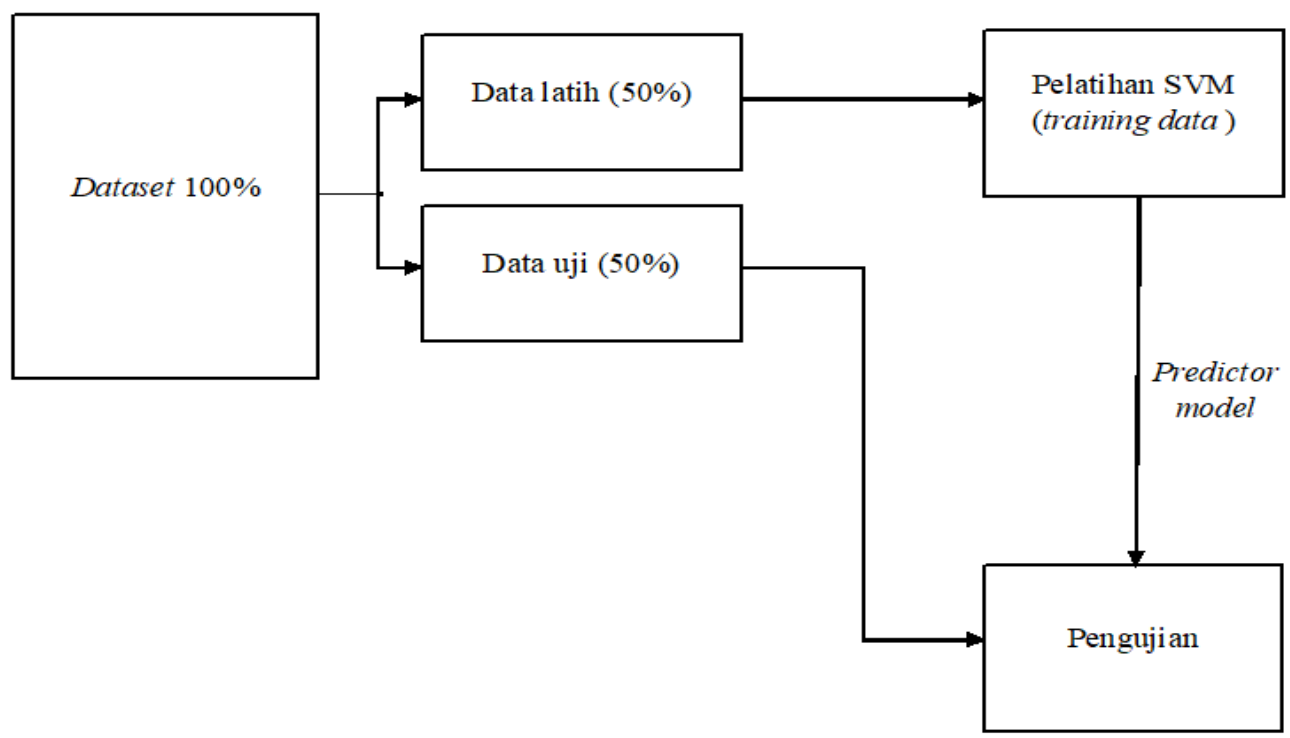

Gambar 3 Diagram blok pembagian data

\subsubsection{Pembelajaran SVM dan Pengujian Sistem}

Tahap pembelajaran SVM pada penelitian ini menggunakan metode klasifikasi one versus one SVM, karena dapat meminimalkan hasil klasifikasi yang ambigu dibandingkan dengan metode one versus all. Metode one versus one diterapkan menggunakan library yang mendukung metode tersebut, yaitu library e1071. Parameter pembelajaran mesin SVM berupa cost, $\gamma$ (gamma) dan jenis kernel ditentukan secara otomatis oleh mesin classifier dari library e1071. Pembelajaran SVM pada data latih menghasilkan predictor model, lalu diuji menggunakan data uji. Gambar 4 memperlihatkan proses pembelajaran SVM dan pengujiannya. 


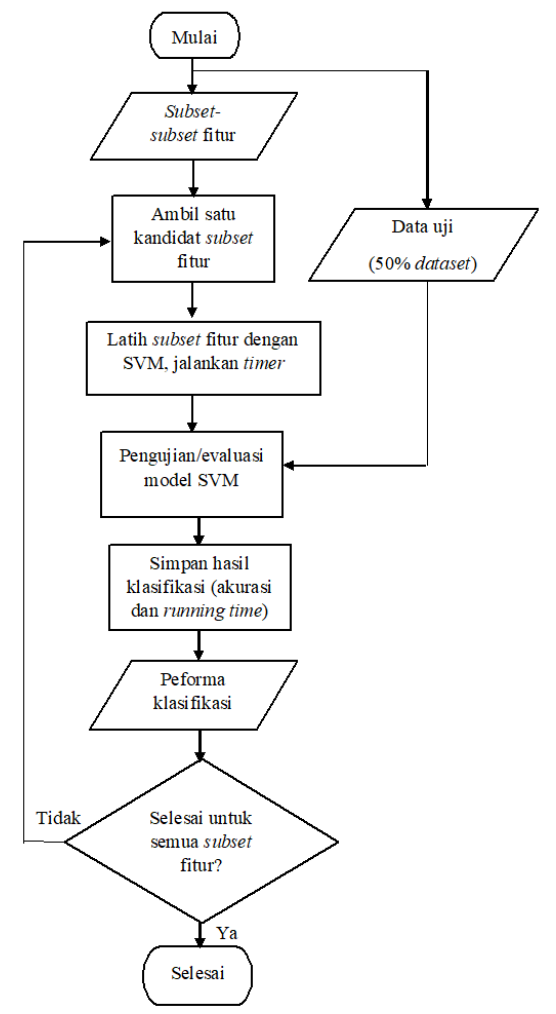

Gambar 4 Diagram alir pembelajaran SVM

Klasifikasi dapat disebut juga sebagai pemetaan dari instance ke class prediksi. Peforma klasifikasi disajikan menggunakan alat visualisasi bernama confusion matrix. Confusion matrix digunakan untuk menunjukkan hubunggan antara hasil dan kelas prediksi. Confusion matrix diperlihatkan pada Tabel 2.

Tabel 2 Confusion matrix

\begin{tabular}{|l|l|l|}
\hline & Predicted positive & Predicted negative \\
\hline Actual postive & TP & FN \\
\hline Actual negative & FP & TN \\
\hline
\end{tabular}

Jika instance adalah positif dan diklasifikasikan sebagai positif maka dikatakan sebagai true positive (TP), jika diklasifikasikan sebagai negatif maka dikatakan sebagai false negative (FN). Jika instance adalah negatif dan diklasifikasikan sebagai positif maka dikatakan sebagai false positive, jika diklasifikasikan sebagai negatif maka dikatakan sebagai true negative (TN).

Tingkat keakuratan klasifikasi ditentukan dengan jumlah klasifikasi yang benar dibagi dengan jumlah total klasifikasi, seperti yang ditunjukkan pada persamaaan 2. Subset fitur baru dan fitur lama (ke 16 sensor) dibandingkan sehingga diketahui perbedaan performa klasifikasinya.

$$
\operatorname{Akurasi}(\%)=\frac{T P+T N}{T P+F P+F N+T N} \times 100 \%
$$

\subsubsection{Pengacakan Data}

Pada penelitian ini dilakukan 10 kali running proses pelatihan. Setiap satu kali running, data akan dilakukan pengacakan. Tahapan ini perlu dilakukan untuk menghindari bias. Nilai akhir akurasi klasifikasi dan running time merupakan rata-rata dari 10 kali running. Gambar 5 memperlihatkan langkah sepuluh kali running dan pengacakan data. 


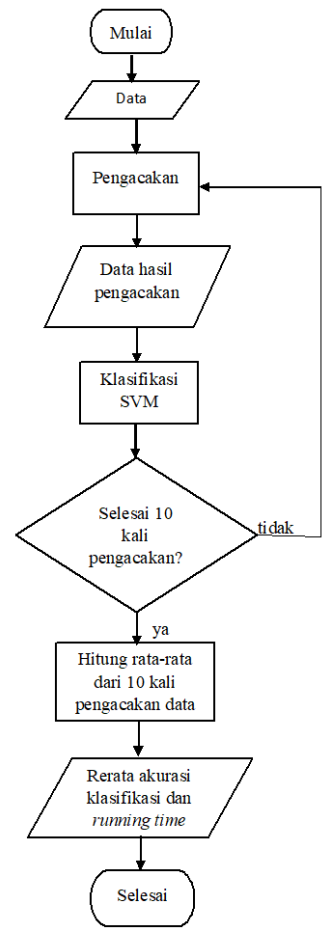

Gambar 5 Diagram alir pengacakan data

\section{HASIL DAN PEMBAHASAN}

\subsection{Repon Sensor}

Data respons sensor didapatkan dari pengujian yang dilakukan oleh Saputro[5] menggunakan sensor electronic tongue terhadap masing-masing sampel selama dua menit dengan pencuplikan data setiap 0,5 detik dan dilakukan sebanyak sepuluh kali, sehingga didapatkan 2400 data untuk masing-masing sampel. Waktu respon terdiri dari dua keadaan, yaitu transient time dan steady state. Penentuan kedua waktu respons tersebut berdasarkan sinyal hasil pengujian sampel yang terlihat pada Gambar 6. Keterangan Gambar 6: (1) respons sensor sebelum dicelupkan ke sampel, (2) transient time dan (3) steady state. Transient time merupakan waktu yang dibutuhkan sensor untuk mencapai kondisi steady state, sedangkan steady state merupakan keadaan saat respons sensor stabil. Sebanyak $10 \%$ data awal respons sensor dibuang sedangkan $90 \%$ data sisanya saat keadaan steady state digunakan sebagai bahan analisis [11].

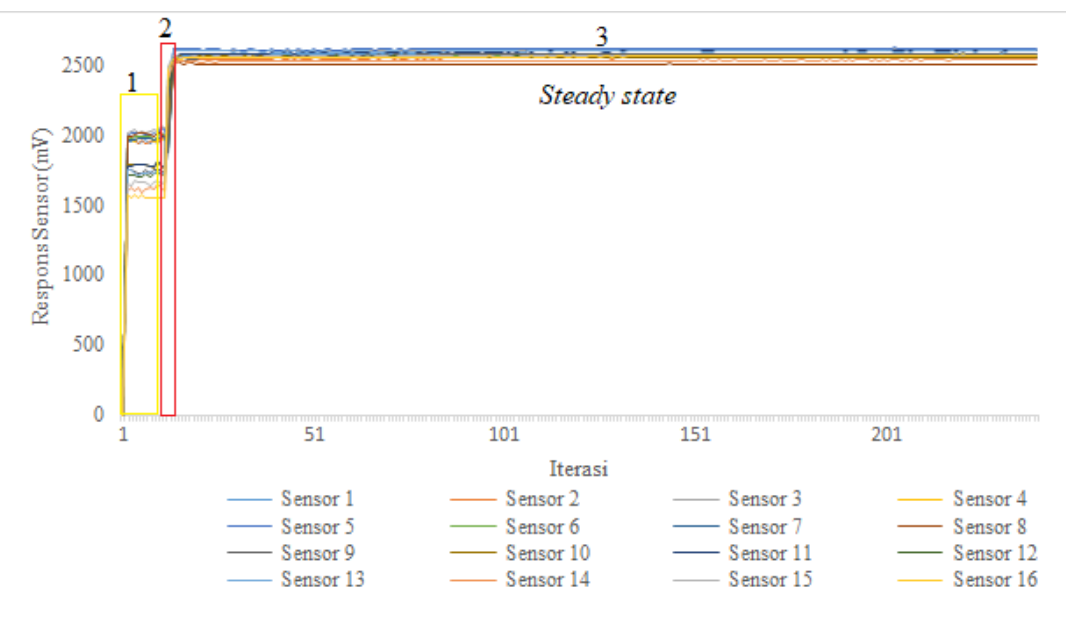

Gambar 6 Respons sensor yang terekam 


\subsection{Ekstraksi Fitur}

Sebelum dilakukan ekstraksi fitur, data respons sensor yang terekam berukuran $216 \mathrm{x}$ 16 untuk satu jenis sampel (setelah prapemrosesan), bilangan 216 merupakan jumlah data pada satu kali pengamatan selama 1,8 menit dan 16 merupakan jumlah sensor yang mengambil data pada saat pengamatan. Setelah dilakukan ekstraksi fitur didapat hasil berupa data digital yang tidak terikat waktu (time independent) berupa sebuah matriks berordo 1 x 16 , dengan 1 merupakan jumlah data yang dihasilkan proses ekstraksi fitur dan 16 merupakan ciri dari sinyal respons sensor yang didapat dari ke 16 sensor. Data ekstraksi fitur dari 10 perulangan dan 4 jenis sampel digabung sehingga didapat sebuah matriks data berordo 40 x 16 .

\subsection{Seleksi Fitur}

Tahap seleksi fitur dilakukan menggunakan metoda PCA kemudian dilakukan pengujian korelasi antar sensor. Analisis data menggunakan PCA menghasilkan grafik scree plot pada Gambar 7 menunjukkan seberapa besar masing-masing PC dapat menjelaskan data asli. Dari kedua scree plot tersebut dapat diketahui bahwa dengan menggunakan dua PC (dimension) saja sudah dapat menjelaskan lebih dari 90\% data asli, yaitu 90,84\% pada sampel ganja-teh dan 94,58\% pada sampel ganja-tembakau, maka analisis loading dan penentuan peringkat kontribusi sensor pada penelitian ini hanya menggunakan PC1 dan PC2.

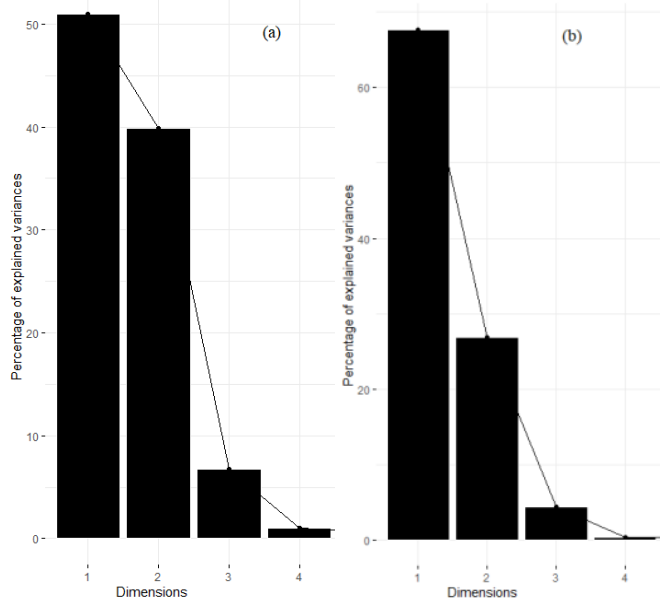

Gambar 7 Scree plot (a) sampel ganja-teh, (b) sampel ganja-tembakau

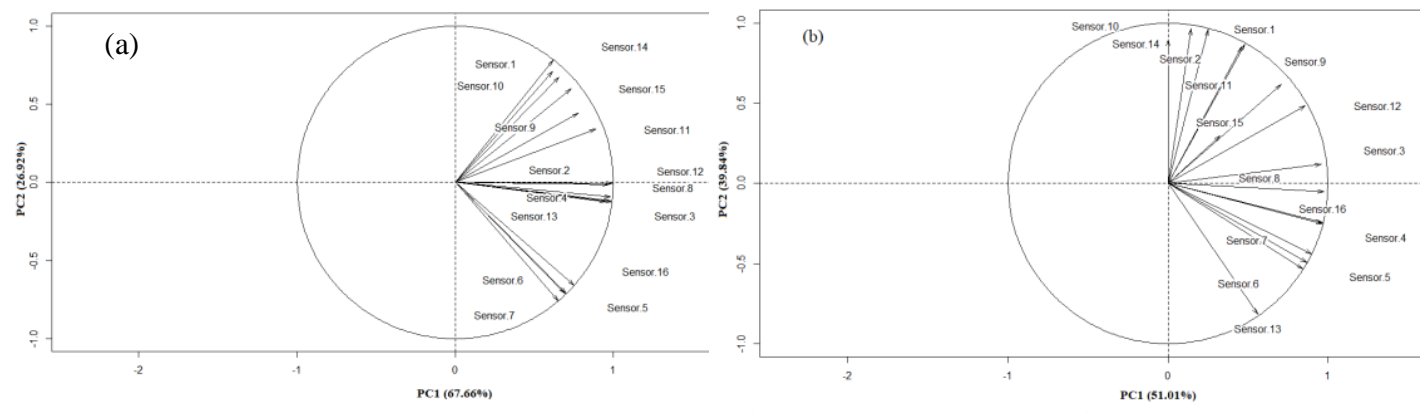

Gambar 8 Loading plot (a) sampel ganja-teh, (b) sampel ganja-tembakau

Besarnya peran variabel asli pada pembentukan variabel baru tidak mengindikasikan peran variabel asli tersebut terhadap pencirian sampel uji. Teori ini harus dibuktikan dengan pengujian klasifikasi menyeluruh pada seluruh variabel (sensor) yang membutuhkan waktu komputasi tinggi. Namun dengan melakukan analisis loading, yang merupakan komponen utama pembentuk persentase kontribusi, menunjukkan kemiripan sifat pada beberapa sensor 
yang ditandai dengan koordinat loading beberapa sensor yang mengelompok, seperti yang terlihat pada loading plot Gambar 8.

Tahap selanjutnya yang dilakukan pada proses seleksi fitur adalah melakukan uji korelasi antar sensor. Pengujian korelasi antar sensor menghasilkan dua jenis nilai, yaitu koefisien korelasi dan p-value korelasi. Subset-subset sensor baru dihasilkan dari hasil sensor dengan korelasi dan kontribusi paling tinggi dan ditunjukkan pada Tabel 3. Kedua subset sensor tersebut kemudian dibandingkan performa klasifikasinya dengan larik sensor semula.

Tabel 3 Subset sensor baru yang dihasilkan dari tahap seleksi fitur

\begin{tabular}{|l|l|}
\hline \multicolumn{1}{|c|}{ Sampel } & \multicolumn{1}{c|}{ Subset Sensor } \\
\hline Ganja-teh & S7, S10, S12, S13, S14, S15 \\
\hline Ganja tembakau & S3, S7, S14 \\
\hline
\end{tabular}

\subsection{Klasifikasi SVM}

Tabel 4 menunjukkan perbandingan hasil klasifikasi antara fitur asli (ke 16 larik sensor) dengan subset fitur baru pada sampel ganja-teh dan pada sampel ganja-tembakau yang dilakukan perulangan dan pengacakan data sebanyak 10 kali.

Tabel 4 Hasil klasifikasi SVM

\begin{tabular}{|l|l|l|l|l|c|}
\hline \multicolumn{1}{|c|}{ Kombinasi sensor } & $\begin{array}{c}\text { Running time } \\
(\mu \mathrm{s})\end{array}$ & $\begin{array}{c}\text { Akurasi } \\
(\%)\end{array}$ & \multicolumn{1}{c|}{ Kernel } & cost & gamma \\
\hline $\begin{array}{l}\text { Ganja-teh } \\
(16 \text { sensor })\end{array}$ & 4,868 & 100 & radial & 1 & 0,0625 \\
\hline $\begin{array}{l}\text { Ganja-teh } \\
(\mathrm{S} 7, \mathrm{~S} 10, \mathrm{~S} 12, \mathrm{~S} 13, \mathrm{~S} 14, \mathrm{~S} 15)\end{array}$ & 4,29 & 100 & radial & 1 & 0,167 \\
\hline $\begin{array}{l}\text { Ganja-tembakau } \\
(16 \text { sensor })\end{array}$ & 5,484 & 100 & radial & 1 & 0,0625 \\
\hline $\begin{array}{l}\text { Ganja-tembakau } \\
(\mathrm{S} 3, \mathrm{~S} 7, \mathrm{~S} 14)\end{array}$ & 3,788 & 100 & radial & 1 & 0,333 \\
\hline
\end{tabular}

Keakuratan hasil pengujian klasifikasi SVM terhadap sampel pada Tabel 5. Nilai akurasi yang mencapai $100 \%$ menandakan kelima data asing dapat diprediksi dengan benar di setiap kelasnya oleh model SVM yang diterapkan pada data latih.

Tabel 5 Confusion matrix pada sampel ganja-teh

\begin{tabular}{|l|c|c|c|c|}
\hline \multirow{2}{*}{\multicolumn{2}{c|}{ Kelas Prediksi }} & \multicolumn{4}{c|}{ Kelas Aktual } \\
\cline { 2 - 5 } & $\begin{array}{c}\text { Ganja- } \\
\text { campurannya } \\
(10: 90)\end{array}$ & Ganja (100) & $\begin{array}{c}\text { Ganja- } \\
\text { campurannya } \\
(25: 75)\end{array}$ & $\begin{array}{c}\text { Ganja- } \\
\text { campurannya } \\
(50: 50)\end{array}$ \\
\hline Ganja- campurannya (10:90) & 5 & 0 & 0 & 0 \\
\hline Ganja murni & 0 & 5 & 0 & 0 \\
\hline Ganja- campurannya (25:75) & 0 & 0 & 5 & 0 \\
\hline Ganja- campurannya (50:50) & 0 & 0 & 0 & 5 \\
\hline
\end{tabular}

\section{KESIMPULAN}

Tahap seleksi fitur yang telah dilakukan menghasilkan jumlah fitur yang lebih kecil, yaitu subset fitur dengan 6 buah sensor (Sensor 7, Sensor 10, Sensor 12, Sensor 13, Sensor 14 dan Sensor 15) pada pengujian sampel ganja-teh dan subset fitur dengan 3 buah sensor (Sensor 3, Sensor 7 dan Sensor 14) pada pengujian sample ganja-tembakau. Kedua subset fitur yang dihasilkan dari tahap seleksi fitur memiliki akurasi pengujian klasifikasi SVM sebesar $100 \%$ dari rerata 10 kali pengujian dengan mempersingkat running time, dengan selisih 0,578 mikrodetik pada pengujian sampel ganja-teh dan selisih 1,696 mikrodetik pada pengujian sampel ganja-tembakau. 


\section{DAFTAR PUSTAKA}

[1] D. Putri and T. Blickman, "Cannabis in Indonesia," no. January, pp. 1-24, 2016. https://www.tni.org/files/publication-downloads/dpb_44_13012016_map_web.pdf

[2] C. M. Andre, J.-F. Hausman, and G. Guerriero, "Cannabis sativa: The Plant of the Thousand and One Molecules," Front. Plant Sci., vol. 7, no. February, 2016. https://www.ncbi.nlm.nih.gov/pmc/articles/PMC4740396/

[3] J. Rabbani, "Rancang Bangun Larik Sensor Rasa berbasis Campuran Lipid TOMA dan OA untuk Klasifikasi Ganja," Universitas Gajah Mada, 2017. http://etd.repository.ugm.ac.id/index.php?mod=penelitian_detail\&sub=PenelitianDetail \&act=view\&typ=html\&buku_id=112287\&obyek_id=4

[4] I. Tazi, "Studi dan Pengembangan Lidah Elektronik berbasis 16 Multikanal Sensor Membran Lipid," Universitas Gadjah Mada, 2017. http://etd.repository.ugm.ac.id/index.php?mod=penelitian_detail\&sub=PenelitianDetail \&act=view\&typ=html\&buku_id=128640\&obyek_id=4

[5] R. E. Saputro, "Pengembangan Larik Sensor E-Tongue berbasis Lipid OA (Oleic Acid) dan TOMA (Trioctyl Methyl Ammonium Chloride) untuk Identifikasi Ganja dan Campurannya," Universitas Gadjah 2017. http://etd.repository.ugm.ac.id/downloadfile/112300/potongan/S1-2017-331380-title.pdf

[6] I. Tazi, K. Triyana, D. Siswanta, A. C. A. Veloso, A. M. Peres, and L. G. Dias, "Dairy products discrimination according to the milk type using an electrochemical multisensor device coupled with chemometric tools," J. Food Meas. Charact., vol. 12, no. 4, pp. 2385-2393, 2018. https://www.researchgate.net/publication/325776120_Dairy_products_discrimination_a ccording_to_the_milk_type_using_an_electrochemical_multisensor_device_coupled_wi th_chemometric_tools

[7] G. Casella, S. Fienberg, and I. Olkin, An Introduction to Statistical Learning with Applications in $R$. Springer Texts in Statistics, 2015. https://www.springer.com/gp/book/9781461471370

[8] J. P. Lander, $R$ for Everyone Advanced Analytics and Graphics Second ED., vol. 7. Pearson Education Inc., 2017.

[9] H. Sun et al., "Sensor Array Optimization of Electronic Nose for Detection of Bacteria in Wound Infection," vol. 64, no. 9, pp. 7350-7358, 2017. https://ieeexplore.ieee.org/document/7902191

[10] E. S. Wahyuni, "Klasifikasi SVM(Support Vector Machine) dan Kombinasi Seleksi Fitur pada Diagnosis Kanker Payudara," Universitas Gadjah Mada, 2014. http://etd.repository.ugm.ac.id/index.php?mod=penelitian_detail\&sub=PenelitianDetail \&act=view\&typ=html\&buku_id $=74052$

[11] N. M. Makarova and E. G. Kulapina, "A new potentiometric sensors for determination of sodium alkylsulfates," in Procedia Engineering, 2014, vol. 87, pp. 284-287. https://www.sciencedirect.com/science/article/pii/S1877705814027854 